\title{
Socialismus mezi demokracií a diktaturou
}

\author{
Martin Šimsa \\ Univerzita Jana Evangelisty Purkyně v Ústí nad Labem, ČR
}

\author{
ŠIMSA, M.: Socialism Between Democracy and Dictatorship \\ Philosophica Critica, vol. 7, 2021, no. 2, ISSN 1339-8970, pp. 41-53.
}

\begin{abstract}
Socialism existed and still exists in several versions. The most famous concept of socialism was projected by Marx and his disciples, but before and after Marx it is also possible to encounter its non-Marxian concepts. We can also distinguish socialism in the form of democracy and socialism in form of a dictatorship. The paper examines mainly democratic versions. Democratic socialism was outlined in the Social Question by T. G. Masaryk. Masaryk's socialism became a decisive source of inspiration for the concept of social democracy, as it was conceived and promoted in exile intellectual and political practice by Karel Hrubý, and for socialism as it was conceived, interpreted and lived in dissent in the 1970s and 1980s by Ladislav Hejdánek. The article also reflects on the critical attitude of Hrubý and Hejdánek to the reform Marxists and to Stalinist dictatorship and its normalization copy (farce).
\end{abstract}

Keywords: Socialism - Democracy - Dictatorship - Masaryk Hrubý - Hejdánek

Socialismus existoval už v 19. století ve více verzích, ale politicky a intelektuálně se u nás i ve světě prosadil zejména marxovský či marxistický. My se zaměřme na masarykovskou verzi socialismu, jak ji Masaryk představil specielně v Otázce sociální a jak tuto verzi socialismu dále promýšleli sociolog, filosof, historik a sociální demokrat Karel Hrubý a protestantsky věřící filosof, mluvčí Charty 77 a socialista Ladislav Hejdánek. Masaryk svou verzi socialismu promýšlel zejména na přelomu 19. a 20. století v konfrontaci se socialismem Marxovým a Engelsovým, Hrubý a Hejdánek $\mathrm{v}$ období po 2 . světové válce, zvláště v době komunistického režimu v konfrontaci se stalinistickou diktaturou, ideologií marxismu-leninismu a tzv. „reálným“ socialismem. Můžeme si položit otázku, zda má smysl o takové koncepci socialismu, v zásadě pojímané jako sociální demokracie či demokratického socialismu uvažovat. Při kladení otázky nelze přehlédnout 
zneužití a diskreditaci pojmu socialismus jejím užíváním pro označení totalitární stalinistické a post-totalitární normalizační diktatury. Existuje šance na rehabilitaci pojmu, který je zatížen tak silnými negativními společenskými a politickými zkušenostmi a totalitární diskurzivní praxí? Na položené otázky budeme hledat odpovědi s vědomím toho, že nebudou a nemohou být zodpovězeny prostřednictvím jednoho konferenčního příspěvku, ale že jejich položení může být přínosné pro případné hledání alternativ v podobě demokratického socialismu.

\section{Masarykův koncept socialismu a demokracie}

Masaryk se zaměřil na Marxe, Engelse, socialismus a marxismus v jednom ze svých dvou největších teoretických děl a to v Otázce sociální, kterou vydává 1898 česky a 1899 německy. (Druhým, ještě rozsáhlejším, dílem bylo Rusko a Evropa.) Masarykův př́stup, důvody, východiska a motivace jsou patrné hned v úvodních větách Otázky sociální. „Sociální otázka tot’ veliký fakt vší té bídy hospodářské a společenské vůbec, bídy hmotné a mravní, kterou všichni a stále máme před očima, at' se díváme na přepych boháčů nebo nouzi proletářů, at' pozorujeme život ve městech nebo na venkově, na ulici nebo v domácnosti... Sociální otázka - to dnes znamená neklid a nespokojenost, touhu a strach, naději a zoufání tisíců a miliónů... Dnes sociální otázka konkrétně a prakticky je otázkou socialismu; v poměrech našich pak socialismus je hlavně marxismem" (Masaryk 2000, 17). Mnohým se zdá, že po pádu komunistických režimů je otázka marxismu i socialismu pasé, přesto stojí za to si připomenout, jak k nim Masaryk přistupoval, co na Marxově a socialistickém přístupu oceňoval a v čem je kritizoval a odmítal. Bude nás zvláště zajímat, co z těchto otázek zůstává dosud živé a otevřené a chceme si položit otázku, zda Masarykova koncepce není v nějakém ohledu dnes živější a aktuálnější než byla ve své době. Na Masarykově přístupu bych podtrhl to, že otázka sociální je pro něj otázkou ekonomické, sociální a mravní bídy a tuto bídu vidí jak v chudobě, tak v nepřiměřeném bohatství, vidí v ní obsaženy emoce strachu, neklidu, nespokojenosti, zoufání, ale i naděje a je pro něj otázkou socialismu, zvláště marxismu.

Masarykův přístup lze dobře charakterizovat jeho vlastní zkratkou, kterou učinil ve svém proslovu v Písku 1906: „Vždy pro dělníka, velmi často se socialismem, zřídka s marxismem“ (Hromádka 1930, 208). Na Marxovi Masaryk oceňuje vyzdvižení otázky sociální a podtržení významu práce, i když ani v otázce sociální ani v pojetí práce se s Marxem neshoduje. Marxovo revoluční pojetí považuje za romantické, v podstatě aristokratické. Marxe podrobuje kritice pro jeho amoralismus, který se 
ocitá v př́́krém rozporu s morálním rozhořčením, s nímž Marx a marxisté kritizují kapitalismus. Masaryk nesdílí ani Marxův materialismus, ateismus a hegelovský dialektický postup. Také se rozchází s marxismem ve věci přeceňování mas a davu, protože masa a dav podle Masaryka neruší osobní odpovědnost, kterou nese vždy jedinec (Masaryk 2000,154).

Reformaci a reformu, nejen náboženskou, ale i etickou a společenskou staví výše či přímo proti revoluci, která vystupuje $\mathrm{v}$ jeho interpretaci jako výsledek ozrušení, rozčilení, aristokratický sport a zábava (Masaryk 2000, 175-211). Kategorické odmítání revoluce se však v Masarykově díle mění. V Amerických přednáškách (1907) píše o reformaci jako o duchovní revoluci (Masaryk 1929, 17-18) a v Rusku a Evropě (1913) už má pochopení pro oprávněnou a legitimní revoluci jako odpověd' na vykořistování a útlak (Masaryk 1995, 1996, 410) a v poslední, bilanční knize, Světová revoluce (1925), se revoluce dokonce dostává do názvu knihy a stává se ústředním tématem zkoumání (Gellner 1995, 45- 58; Masaryk 1930). I když je zřejmé, že mu jde o demokratickou revoluci, tak ho Gellner vystavuje kritice, že názvem díla pomohl pozdějším komunistům legitimizovat jejich vlastní revoluci, i když měla jiný obsah než Masarykovo dílo a že anglický překlad Making the State (tedy Budování státu) je přesnějším vyjádřením obsahu Masarykova díla než Světová revoluce. Pro Masaryka světovou revolucí byla demokratická revoluce, o jejímž úspěšném postupu byl přesvědčen, v této věci navazoval na Tocquevilla a soudím, že ne neoprávněně, byt' se to nedálo tak lineárně, jak oba ve svých knihách popisovali a představovali. Při hlubší analýze Masaryka bychom museli rozlišit jeho dílo podle toho, ve které době psal a v jaké roli působil: 1. Před (První světovou) válkou byl národní a sociální kritik a reformátor. 2 . Za války byl revolucionář, vůdce zahraničního, diplomatického a vojenského odboje. 3. Po válce prezident, budovatel demokratického státu. Dobový kontext a společenské a politické role, v nichž Masaryk hrál své party, spoluurčovaly význam toho, co ř́kal a dělal.

Masaryk staví demokratickou práci proti aristokratickému sportu a zábavě. Demokratická je pro Masaryka láska, kterou chápe jako řeckou agapé, tedy láska k bližnímu na praktické a sociální rovině. Je jedním z nejsilnějších Masarykových pojmů. Celou kapitolku nazývá „Moderní láska: láska demokratická", tedy láska, která je účinná, energická, není slepá, romantická, mystická a fetišistická (Masaryk 2000, 150). Láska je v Masarykově interpretaci spojená s prací, etikou a solidaritou (Masaryk 2000, 151-152). Láska je základem ústředního Masarykova pojmu, pojmu humanity i ideálů humanitních. Demokracii Masaryk definuje také jako politickou formu lásky k bližnímu, tedy láska má v Masarykově pojetí sociální i politický rozměr. 
Masaryk ukazuje, že mladý Marx jako radikální demokrat se zároveň hlásí k republikanismu: „Principem monarchie vůbec je člověk opovržený, opovržitelný, člověk odlidštěný", naproti tomu skutečným a pravým člověkem byly by „bytosti duchové, mužové svobodní, republikáni“ (Masaryk 2000, 213). Zároveň ukazuje, že jinde Marx tvrdí, že stát, který nedokáže odstranit bídu a pauperismus je mu lhostejný, či dokonce, že stát, který by chtěl odstranit bídu, by musel zrušit sám sebe, protože přičina zla tkví ve státě samém a tento anarchismus rozhodně odmítá (Masaryk 2000, 213).

Masaryk byl velkým kritikem ruského, přesněji sovětského bolševismu, ale ten $v$ jeho koncepci neměl se socialismem nic společného. Bolševismus je pro Masaryka horší verzí ruského komunismu - carismus naruby. Bolševismus kritizoval v několika studiích, v nichž ukazoval absurdnost tvrzení, že bolševici chtějí stavět socialismus či dokonce komunismus na vědeckém ateismu a přitom jich většina neumí ani číst a psát. Rovněž, že je ruský bolševismus stavěn shora a ne zdola, neřídí se žádnými demokratickými principy, pouze zavádí diktaturu Lenina a jeho druhů. Bolševici byli schopni za vhodných okolností provést politickou revoluci, ale nebyli schopni stálé, drobné, klidné, systematické hospodářské práce. Studie „Revoluce a bolševici“ a „O takzvané diktatuře proletariátu“ psal v roce 1921 (Masaryk 1921) a v té době ještě netušil, jaká hrůzovláda a krutovláda nastoupí za vlády Stalina, který dovedl Leninovu diktaturu ke zvrácené dokonalosti. Bolševictví rovněž kriticky analyzuje o čtyři roky později ve Světové revoluci (Masaryk 1930, 198-208). Masaryk poukazuje a navazuje na kritiku Kautského a Bernsteina. Pro Masaryka je socialismus možný jen jako domyšlení demokratických principů i do poměrů hospodářských a sociálních, předpokládá vzdělanost, kulturu a kritické myšlení a to bylo zcela neslučitelné se sovětským bolševismem, ale i s tím, co českoslovenští komunisté nazývali „lidovou demokracií“ a posléze „socialismem“ či „reálným socialismem“

Socialismus byl už v době, kdy Masaryk psal Otázku sociální převážně marxistický a to během Masarykova života ještě zesílilo, tím spíše pak po jeho smrti. Proto si musíme položit otázku, zda Masarykův nemarxistický socialismus představuje aktuální politicko filosofické a politické téma i po jeho smrti. Hrubý a Hejdánek jsou dokladem toho, že v českých zemích zůstal živý nejen Masarykův koncept demokratické republiky, ale i Masarykův koncept socialismu, demokratického socialismu, který do značné míry mohl být i programem sociální demokracie. 0 to se konkrétně pokoušel Karel Hrubý. Masaryk sám sociálním demokratem nebyl, ale mezi Masarykem a sociální demokracií existovaly oboustranné sympatie. Masaryk dává sociální demokracii za vzor mladočechům a staročechům v České otázce jako př́iklad moderní demokratické strany oproti 
stranám budovaným pouze na českém nacionalismu. Na námitku, že Karel Marx je německý myslitel odpovídá protiargumentem, že Herder byl také německým myslitelem a stal se inspirací pro české národní obrození (Masaryk 1969, 233-237). Sociální demokraté umožnili Masarykovo zvolení za malou realistickou stranu ve volbách za Valašsko tím způsobem, že do obvodu nepostavili proti němu svého protikandidáta, ale sami ho podpořili.

\section{Hrubý o Masarykovi, socialismu a diktatuře}

Pro výklad života a díla Karla Hrubého jsou povolanější autoři, ale v tomto př́spěvku se chci zaměřit na dva momenty Hrubého díla, jeho recepci Masaryka, zvláště Masarykova demokratického socialismu a na intenci, že nedemokratický socialismus není socialismem a že politický program sociální demokracie není myslitelný bez jasné a srozumitelné koncepce demokracie, že pouhý populismus, nacionální populismus či populistický nacionalismus nestačí. $V$ tomto směru Hrubý velmi pregnantně argumentoval před třemi lety v textu publikovaném v Deníku Referendum věnovaném sebe-porozumění či spíše sebe-neporozumění sociální demokracie (Hrubý 2021).

Z Masaryka Hrubý přijímá jeho pojem humanity, kterou interpretuje zejména jako odporování zlému, samotné Masarykovo užívání pojmu humanity spolu s Kaizlem, Pekařem a Patočkou kritizuje jako nevyjasněné. Zaznamenání hodný je bystrý postřeh, že základem Masarykovy koncepce, je křest’anská interpretace zlého jako pocházejícího z ducha, ne z hmoty (platonismus) či z poměrů (marxismus) (Čapek - Hrubý, 1981). Podobně jako Masaryk zdůrazňuje možnost svobodné volby mezi správným a nesprávným, dobrým a zlým a odpovědností či neodpovědností jednotlivce. Myslím, že z této masarykovsky pojaté odpovědnosti vyrostlo Hrubého angažování se v komunisty zlikvidované sociální demokracii, za což si vysloužil v druhé půli padesátých let pět let vězení a posléze i v exilu, kde se velmi zasloužil o to, že sociální demokracie měla po roce 1989 na co navázat, $\mathrm{v}$ čem pokračovat, i když v současnosti to není na její politice př́liš patrné, nicméně v myšlenkově světlejších okamžicích polistopadové sociální demokracie se exilová práce ukazovala a projevovala. Hrubý pokračuje $\mathrm{v}$ teoretické, kriticky interpretační práci $\mathrm{v}$ době polistopadové a vstupuje do současných historických a sociologických diskusí týkajících se interpretace jak minulosti, tak současnosti.

Co se týče Hrubého recepce Masaryka, připomněl bych, že Hrubý byl spolu s Miličem Čapkem editorem reprezentativního exilového masarykovského sborníku T. G. Masaryk in Perspective. Comments and Criticism, 
vydaného Československou společností pro vědy a umění v roce 1981 s př́spěvky Patočky, Čapka, Koháka, Jakobsona, Lochmana, Černého, Hrubého, Kovtuna, Welleka, Krejčího, Belda, Štefáneka, Szporluka, Nováka a Voskovce (Čapek - Hrubý, 1981) My si přiblížíme Hrubého příspěvek zařazený do sekce filosoficko-historické.

Hrubý Masaryka charakterizuje ne jako čistě teoretického filosofa, ale rozeného sociálního reformátora, pro kterého byla filosofie př́pravou na efektivní, racionálně odůvodněnou a systematickou veřejnou aktivitu. Kriticky reflektuje filosofické kořeny Masarykova politického pohledu. Za předpoklady Masarykovy politické aktivity považuje jeho etický program, pokyny pro tvoření dějin, víru v pokrok, sociální a politický optimismus, determinismus, který pro Masaryka znamenal nexus mezi minulostí, přítomností a budoucností. Hrubý rozlišuje v Masarykově politickém myšlení prvek národně-kulturní, státně-politický a kulturně filosofický. První prvek byl rozpracován v České otázce při hledání české identity a autonomie vedené ideálem humanity v období od devadesátých let devatenáctého století do První světové války. Státně politický program je rozpracován v Nové Evropě a Světové revoluci, cílem bylo ustavení a uznání nezávislého československého státu a nahrazení monarchie a aristokracie demokracií. Poslední prvek vidí rozpracován v Sebevraždě, Otázce sociální, Moderní člověk a náboženství, Rusko a Evropa. Zde se podle Hrubého nacházejí filosofické kořeny Masarykova sociálního a politického myšlení včetně myšlení evropského. Hrubý s náznakem kritické distance píše o Masarykově duchovním a politickém eurocentrismu. Masarykovy fundamentální filosofické otázky Hrubý vidí v jeho metafyzické otázce, koncentrované zvláště v pojmu svobody, v historické otázce, vedené zvláště smyslem a filosofií dějin, v etické otázce, která se soustřed'uje zejména na pojem humanity a sociální otázce, v níž dle Hrubého dominuje demokracie, vedená progresivním liberalismem 18. století a socialismem 19. století, které čte jako ovoce anglo-saského protestantismu. (Hrubý 1981, 119-130). Namítl bych, že Masaryk preferuje britskou (liberální) a americkou (náboženskou) demokracii zvláště pro odluku státu a církve před francouzskou, ale citlivost pro sociální otázku a pro socialismus připisuje Němcům.

Hrubý se inspirativně vyrovnává s Masarykovými kritiky, přejně zmiňuje Kaizla, Werstadta i Modráčka. Modráček Masarykovi namítal, že jeho pojetí demokracie je jen duchovní a kulturní, ale sociálně je neúčinné. Masarykovi pováleční kritici, Stránský, Peroutka a zvláště Nehněvajsa namítali, že Masarykův koncept demokracie nepřežil konec první republiky. Nehněvajsa uváděl, že Masaryk předložil pouze sociologické spekulace a budoucnost vykreslená optimistickými termíny se ukázala nerealistická. Cituje Václava Černého, že Masarykovo pojetí historického češství je 
neobhajitelné a právě tak jeho optimistická víra v konečnost „světové revoluce 1914/18“. Hrubý podrobně referuje na Patočkovu kritiku, která se do značné míry shoduje s Černým, nadto ukazuje rozpory mezi masarykovským pozitivistickým historickým objektivismem, prozřetelností a moralismem. Také mu vyčítá, že vůbec nepředpokládal hrůzy nacismu, nové války a nové totalitarismy (Hrubý 1981, 130-134).

Hrubý Masaryka hájí argumentem, že není fér ho obviňovat, že selhal jako politický prorok. Jeho koncepce byla úspěšná v jeho době. Podrobuje kritice Masarykův koncept demokracie postavený na anglo-saském a českém protestantismu jako společensky neúnosných v českých zemích a tím spíše na Slovensku, když většina obyvatelstva byla katolická a později dokonce ateistická. Soudí, že Masaryk věřil v renesanci protestantské tradice. Uznává, že Masaryk odvozuje z protestantismu koncept individualismu. Za jisté dědictví Masarykova individualismu a tolerance považoval hnutí Charty 77, protože se v ní sešli protestanté, katolíci, komunističtí ateisté, liberálové, sociální i křestanští demokraté. V hnutí Charty Hrubý vidí spíše působení Kantova kategorického imperativu než univerzální metafyziky. Hlavní přínos Masarykova politického myšlení spatřuje v důrazu na individuální svědomí a odpovědnost proti kolektivním zlům, která přišla po Masarykovi a plula na vlnách animální iracionality. Dává za pravdu Masarykovým kritikům, tedy Kaizlovi, Černému a Patočkovi v kritice toho, že národní dědictví nelze ztotožnit s jednou tradicí, ale zároveň oceňuje, že Masaryk vytvořil jak kulturní, tak morální program České otázky, tak program demokratického československého státu, do něhož vtělil západní evropskou kulturu (Hrubý 1981, 119-138).

Kdybychom chtěli odpovědět Hrubému a Masarykovým kritikům, tak bychom museli zdůraznit, že Masarykova koncepce demokracie je až doposud jedinou domácí ucelenou koncepcí demokracie i se všemi svými nedostatky a chybami, na něž upozorňovali Rádl, Černý, Patočka a právě tak sám Hrubý, ale že tyto korektury zásadně nepřekračují Masarykem načrtnutý rámec. Masarykova koncepce dalšího šíření americké a evropské demokracie se v dlouhodobém horizontu ukázala jako správnější než skepse jeho kritiků, byt' se to nedálo tak lineárně, jak Masaryk předpokládal v bilančně optimistické Světové revoluci. Do budoucna je třeba více pracovat s pluralistickým konceptem demokracie, který nemůže být vázaný jen na českou reformační a protestantskou tradici.

Hrubý přejně analyzuje podobnosti Masarykovy a Bernsteinovy koncepce sociální otázky a socialismu (Hrubý 2018,128-145) a spíše kriticky hodnotí původně mladé komunistické intelektuály pro jejich přiklonění k marxismu-leninismu, s určitým uznáním analyzuje jejich „prozření a poučení z období stalinistické diktatury. Věcně, kriticky, inspirativně 
rozebírá životní, literární, společenské i politické dílo Zdeňka Mlynáře, Karla Kosíka, Roberta Kalivody, Ivana Klímy, Milena Kundery, Pavla Kohouta a Ludvíka Vaculíka a jejich pokus o model demokratického socialismu v roce 1968 (Hrubý 2018, 146-221).

\section{Hejdánkovy perspektivy demokracie a socialismu}

Hejdánek se po válce myšlenkově formoval v Akademické Ymce, křest’ansky ekumenické organizaci pro mládež, v níž se stal předsedou vysokoškolské pražské sekce, kde ho silně ovlivnil zejména J. L. Hromádka, ale také J. B. Souček, Jan Patočka a Božena Komárková. Hejdánek studoval Marxe a marxismus, říká sám o sobě, že nebyl dalek od vstupu do komunistické strany (Hejdánek 1933, 33), ale nikdy do ní nevstoupil. Vedle Hromádky pro něj byli orientační myslitelé Masaryk a Rádl, které se svými přáteli v Ymce na konci čtyřicátých a na počátku padesátých let intenzivně studovali. ${ }^{1}$ Ymka byla komunisty rozpuštěna v roce 1950 . Hejdánek dostudoval filosofii v roce 1952 jako veřejně deklarovaný ne-marxista, který se přesto hlásil k programu socialismu. Masaryka četl s Rádlovými korekturami, formativní pro něj bylo zejména Rádlovo pojetí pravdy i Rádlovo pojetí spravedlivé, „ne-nacionální“ demokracie. Rádl byl rovněž sociální demokrat, ale vůči Marxovi a marxismu kritičtější než Masaryk. Ukazoval závislost marxismu na ekonomickém liberalismu, konkrétně na jeho negaci. „Proti tomuto materialismu liberalistickému Marx bojoval materialismem socialistickým a stavěl proti egoismu a násilí jednotlivcovu egoismus a násilí masy“ (Rádl 1993, 140). Hejdánek podobně jako Hromádka odvozoval sociální nárok a praxi z židovských proroků a z Ježíšovy starosti o vdovy a sirotky, tedy o slabé a chudé, o ty, kdo se nacházejí na okraji společnosti.

Nebudeme procházet Hejdánkův filosofický vývoj, do něhož patří zvláště rozvíjení nepředmětného ontologického (méontologického) myšlení a Havlíčkova a Masarykova nepolitická politika, ale všimneme si obrany lidských práv, která byla filosoficky zakotvena v nepředmětném pojetí pravdy, práva a spravedlnosti. Hejdánek byl k nepředmětnému myšlení inspirován zejména Patočkovým pojetím negativního platonismu. Otázky pravdy, práva, spravedlnosti, lidských práv a demokracie přebíral z Masaryka a Rádla, chápal je normativně, odmítal jejich „přirozený“,

\footnotetext{
HEJDÁNEK, L. (1949): Význam Masarykova pojetí pravdy pro myšlení Kozákovo, Hromádkovo a Rádlovo. Dosud nepublikovaný studentský referát pro Riegerův seminár. 40 strojopisných stran. Scan kopie Archívu Ladislava Hejdánka. HEJDÁNEK, L. (2018): Rádlovo pojetí pravdy. In: Šimsa, M. (ed.): Relativismus $a$ (post)pravda $v$ demokracii. Se třemi studiemi Ladislava Hejdánka. Ústí nad Labem, FF UJEP, s. 279-313
} 
„naturalistický“ původ a nově je interpretoval a aplikoval do poměrů stalinistické a „normalizační" diktatury.

Necháme stranou Hejdánkův socialismus v padesátých a šedesátých letech, kdy považoval za nutnější se brát za reformní, novoorientační křest'anství, ale podíváme se na jeho socialismus let sedmdesátých a osmdesátých a na skutečnost, že za socialistu se prohlásil i v roce 2008 na retreatu Akademické Ymky ve Varvažově u Písku. Co ovšem nelze přejít, je Hejdánkův podíl na dialogu křestanů a marxistů, kde se zvláště orientoval na filosofický dialog s Kosíkem. Dialektice konkrétního věnoval několik recenzí, v nichž se zaměřuje zejména na Kosíkovu filosofii člověka, ontologii praxe a autentický život a umění (Hejdánek 2010, 31-34, 35-63, 107-115).

Hejdánek spolupracoval s reformními komunisty, ač sám komunistou nikdy nebyl, už počátkem sedmdesátých let, konkrétně v letákové kampani k volbám v roce 1971 organizované „komunisty v opozici“ Jaroslavem Šabatou a Janem Tesařem. Pro svou účast na této akci si odseděl půl roku ve vězení. Doporučil Václavu Havlovi a Jiřímu Němcovi, aby se jedním z mluvčích Charty stal bývalý reformní komunista Jiří Hájek a s Jiřím Hájkem dvakrát vykonával funkci mluvčího Charty. Jednu dobu ji vykonával i s Jaroslavem Šabatou, který Jiř́iho Hájka vystřídal. Po uvěznění Jiřího Dienstbiera a Václava Bendy v roce 1979 nastoupil s Jiř́m Hájkem znovu na jejich místa mluvčích Charty 77. V sedmdesátých letech psal Dopisy př́teli, v nichž vysvětluje své křest'anské, demokratické i socialistické přesvědčení. Nejucelenějším textem je Hejdánkova studie, která se jmenuje Perspektivy demokracie a socialismu ve východní Evropě do československo - polského sborníku publikovaného v roce 1979, do kterého ovšem dodali texty pouze Češi a Slováci, Poláci ne. Dříve než se detailněji podíváme na tento text, zmíníme, že byl rovněž jedním ze signatářu textu Sto let českého socialismu, podepsaný rovněž Václavem Havlem. Tohoto textu si ve svých studiích všímá a pečlivě ho analyzuje Karel Hrubý (Hrubý 2010, 109-110).

V Perspektivách demokracie a socialismu Hejdánek o socialismu píše: „Dnes musí být každému uvažujícímu člověku jasno, že socialismus je dítětem liberálně demokratických tradic a že má daleko k tomu, aby ohlašoval nebo dokonce představoval novou historickou epochu nebo, jak se domníval Marx a jeho přívrženci, novou společensko-ekonomickou formaci. Socialismus má své dějinné oprávnění jako domyšlení a praktické dotažení demokratických principů do oblasti sociální a hospodářské. Socialismus je demokracie dovedená do všech důsledků. Tam, kde bylo řešení sociálních požadavků násilně odtrženo od demokratické základny a kde ve jménu sociálního pokroku byly likvidovány demokratické struktury nebo kde byly alespoň maximálně vyprázdněny, dostal se socialismus historicky do slepé uličky a stal se odstrašujícím př́ikladem, varujícím ty, kteří chtěli jít v jeho 
stopách. Aby skutečnost takového deviovaného socialismu byla zakryta, stala se ze socialistického programu ideologie, zastírající navíc i mocenskou expanzi, která využívá socialismu a socialistických nálad jako strategické zbraně“ (Hejdánek 2018, 323). Hejdánkův pojem socialismu je masarykovský, tedy domyšlení demokracie do hospodářských a sociálních poměrů, ale adresuje Masarykovi podobnou kritiku jako Patočka, Černý a Hrubý, že „podcenil nebezpečí protirevolučních zvratů a zejména neodhadl dobře, jak mocně bude politický život Evropy pod ruským vlivem zasažen socialistickou deviací, která ve jménu hospodářské a sociální spravedlnosti podlomí nebo vyprázdní demokratické programy porevoluční společnosti a samotných revolučních programů“ (Hejdánek 2018, 315).

V Dopisech prríteli Hejdánek na řadě míst vykládá nutnost provázanosti demokracie a socialismu a v čem jsou lidská a občanská práva a demokratické principy pouze $v$ politické rovině nedostatečné a $v$ čem a jak potřebují také sociální rozměr a konkrétní sociální praxi, která však nemá být jen praxí státní a politickou, ale také praxí občanskou, tedy že vše, co lidé a občané mohou udělat sami, mají udělat a nemají čekat, až to bude řešit stát. Za pozornost jistě stojí, jakým způsobem Hejdánek uvažuje o provázanosti komunismu a socialismu s křestanstvím a evropskou myšlenkou a kulturou. „Mezi komunismem a křest'anstvím je totiž jisté velmi těsné pouto: komunismus vyrostl na křestanské půdě a bez křest’anství není historicky vůbec myslitelný. A křest'anství i komunismus nesou na sobě výrazné a neodlučné rysy evropské. Recentní polemika o pojmu a skutečnosti tzv. eurokomunismu a zejména kritika sovětská a vůbec východoevropská naprosto nedbá skutečnosti, že komunismus je idea evropská a že tedy skutečný komunismus je ,eurokomunismus'. Totéž platí o socialismu: ani socialismus není myslitelný bez předpokladů evropské kultury a civilizace a bez vývoje evropského myšlení" (Hejdánek 1993, 105).

Na několika místech interpretuje socialismus jako kritickou reakci na kapitalismus a tlak na jeho změnu či polidštění. „Obrovský hospodářský vzmach, založený vnitřně na vykořistování proletariátu a vnějšně na vykořistování kolonií, vyústil v nepředstavitelné katastrofy. Nadešel konec Evropy? Nadešel zánik Západu? Nikoliv. Konec ještě nenastal, protože se zrodilo cosi nového: vznikl socialismus. Po prvních nejistých krocích se vedoucí představitelé nového hnutí zorientovali: má-li socialismus mít budoucnost a má-li se stát budoucností Evropy a pak celého světa, musí navázat na to nejlepší, co Evropa dovedla až dosud vyprodukovat, co dovedla dát lidstvu“ (Hejdánek 1993, 107). Tuto myšlenku potom detailněji promýšlí a rozvádí v už zmiňované přednášce o socialismu na retreatu Akademické Ymky ve Varvažově u Písku v roce 2008. Přednáška se jmenovala: Spravedlivější společnost: Iluze nebo výzva? (Osudy a možnosti 
socialismu). Hlavní teze přednášky zněla: Pokud tu bude kapitalismus, bude tu i socialismus, protože socialismus byl a je pokusem, jak polidštit nelidské rysy kapitalismu. "Socialismus v historickém smyslu vznikl jako reakce na kapitalismus, tj. na nadále neudržitelné společenské poměry, jaké nastaly v nejpokročilejších evropských společnostech s počátkem industrializace a kolonizace. Zároveň však platí, že významným způsobem navazoval na celou řadu starších hnutí, vyvolaných utlačováním a vykořist'ováním“ (Hejdánek 2008, 6).

Ale uznává jen demokratický socialismus, tedy ten, který bere demokracii jako nutnou podmínku své existence, respektuje každého člověka, ale je zaměřen zejména na podporu a zrovnoprávnění chudých, utlačených, nacházejících se na okraji společnosti a na odstranění nespravedlivých podmínek a bariér. „V mém pojetí (které jsem držel po dlouhá desetiletí i před listopadem) je socialismus domyšlení demokracie a demokratismu do sociálních důsledků. Socialismus, který ruší své demokratické předpoklady, svou takř́kajíc „základnu“, přestává být skutečným socialismem. To, v čem jsme po válce (po druhé světové válce) žili, byl deviovaný a degenerovaný socialismus, čili jinak: nebyl to skutečný socialismus“" (Hejdánek 2008, 16).

Reflektuje současnou situaci ohledně socialismu jako v zásadě plnou ideologických předsudků, ale nebojí se mluvit i o budoucnosti socialismu. „Mluvit dnes a zejména u nás o „socialismu“ znamená okamžitě se dostat doprostřed ideologických půtek a sporů, plných neujasněných myšlenek a předsudků. Jediným lékem je jistá domluva o významu toho slova, abychom mluvili o „téže“ věci. Ale říci něco o budoucnosti socialismu, to předpokládá ještě jakýsi významný krok navíc: nepůjde jen o vymezení významu slova, nýbrž o zaujetí jasného a zřetelného vztahu k socialismu. Nejde tu totiž o odhad nějakých trendů a tendencí, tj. o jakousi „prognózu“, spočívající v protahování již existujících setrvačností do jinak prázdné budoucnosti. Budoucnost socialismu (podobně jako budoucnost umění nebo třeba filosofie) spočívá v tom, jakým způsobem si tyto útvary, tato hnutí, tyto aktivity zachovají, nebo ještě spíše jaké nové si dokáží vytvořit ve vztahu k budoucnosti. 0 tom nemusí - a já jsem přesvědčen, že nebude rozhodovat minulost, to znamená dosavadní podoba všeho toho, čemu se ř́kalo a říká, eventuelně co se samo k tomu hlásí a co samo o sobě říká, že je socialistické a že je tím pravým „socialismem“ (Hejdánek 2008, 14).

\section{Závěr}

Pojem socialismu byl zprofanován a zdiskreditován politickou praxí minulého režimu, zvláště napodobováním „sovětského vzoru“, historik Jaromír 
Procházka to nazýval „diktatura sovětského typu“ (Procházka 1992, 41-43), tedy stalinismu a brežněvismu u nás transformovaného do tzv. normalizace. Socialismus se u nás uskutečnil pouze jako stalinistická diktatura nebo jako tzv. „reálný socialismus“, jímž byl myšlen sociální stát, konzumní společnost a měkčí typ diktatury, v němž jsou pronásledováni jen političtí odpůrci, kritičtí intelektuálové, z větších skupin nekonformní křestané a vlasatá mládež (underground), většina společnosti, pokud se chovala apoliticky a zajímala se jen o svá auta, chaty a dovolené u Černého či Baltického moře, mohla v klidu žít svůj každodenní život.

O Masarykově, Hrubého a Hejdánkově politickém myšlení mluvíme jako o socialismu jen s velkými rozpaky, protože se to vzpírá běžné řečové praxi a většinově sdílené politické zkušenosti. Na prvním místě jsou demokraté či sociální demokraté a socialismu jako sociální demokracii se v našich končinách nedařilo a ani nyní příliš nedaří, naopak jsme svědky pokusu o jakýsi sociální či sociálně nacionální populismus. Cílem tohoto příspěvku však bylo tuto možnost přiblížit a zpřítomnit a pokusit se revidovat vulgárně komunistické i vulgárně antikomunistické ztotožňování socialismu s diktaturou a naopak zdůraznit a podtrhnout tuto zcela legitimní, i když v našich poměrech dosud nerealizovanou možnost.

Soudím, že v př́ípadě všech tří autorů můžeme mluvit nejen o sociální demokracii, ale i o demokratickém socialismu. Smysl to má, jen bude ještě nějakou dobu trvat než humanitní a společenští teoretici a publicisté budou ochotni akceptovat $\mathrm{v}$ diskurzivní praxi socialismus v demokratické formě, v současném demokratickém diskurzu. Všichni tři diskutovaní autoři vykonali poměrně dost teoretické i politické práce pro to, aby se demokratický socialismus vrátil na politicko-filosofickou, společenskou i politickou mapu. K plné rehabilitaci pojmu socialismus bude však pravděpodobně ještě dosti dlouhá cesta. Dílo pojednávaných tří autorů reprezentuje silný a živý inspirační zdroj a ti, kdo by chtěli znovu zdvihnout prapor demokratického socialismu či autentické a evropské sociální demokracie, mají na co navázat.

\section{Literatúra}

ČAPEK, M. - HRUBÝ, K. (1981): T. G. Masaryk in Perspective. Comments and Criticism.

Washington, DC: SVU Press, Československá společnost pro vědy a umění. Czechoslovak Society of Art and Sciences, Inc.

GELLNER, E. (1995): The Price of Velvet: Thomas Masaryk and Václav Havel. In: Czech Sociological Review, 3 (1): 45 - 58.

HEJDÁNEK, L. (1949): Význam Masarykova pojetí pravdy pro myšlení Kozákovo, Hromádkovo a Rádlovo. Dosud nepublikovaný studentský referát pro Riegerův seminár. 40 strojopisných stran. Scan kopie Archívu Ladislava Hejdánka. 
HEJDÁNEK, L. (1993): Dopisy př́teli. Praha: Oikoymenh.

HEJDÁNEK, L. (2008): Spravedlivější společnost: Iluze nebo výzva? (Osudy a možnosti socialismu). (Přednáška). Web. <https://www.hejdanek.eu/Archive/Detail/ 2132?q=socialismus>.

HEJDÁNEK, L. (2010): Filosofie člověka. Ontologie a pojem praxe. Umění a život v autentičnosti. In: Hejdánek, L.: Setkání a odstup. Praha: Oikoymenh, 33 - 34, $35-63,107-115$.

HEJDÁNEK, L. (2018): Perspektivy demokracie a socialismu ve východní Evropě. In: ŠIMSA, M. (ed.): Relativismus a (post)pravda v demokracii. Se třemi studiemi Ladislava Hejdánka. Ústí nad Labem: FF UJEP, 314 - 335.

HEJDÁNEK, L. (2018): Rádlovo pojetí pravdy. In: Šimsa, M. (ed.): Relativismus a (post)pravda v demokracii. Se trememi studiemi Ladislava Hejdánka. Ústí nad Labem: FF UJEP, 279 - 313

HROMÁDKA, J. L. (1930): Masaryk. Praha: YMCA.

HRUBÝ, K. (1981): The Philosophical Roots of Masaryk's Political Outlook. In: Čapek, M. - Hrubý, K. (eds.): T. G. Masaryk in Perspective. Comments and Criticism. Washington, DC:, SVU Press, Československá společnost pro vědy a umění. Czechoslovak Society of Art and Sciences, Inc.

HRUBÝ, K. (2018): Cesty komunistickou diktaturou. Praha: Argo.

MASARYK, T. G. (1921): O bolševictví. Praha: Knihovnička Služby.

MASARYK, T. G. (1929): Americké prednášky. Praha: Čin.

MASARYK, T. G. (1930): Světová revoluce. Praha:Orbis a Čin.

MASARYK, T. G. (1969): Česká otázka. Praha: Melantrich

MASARYK, T. G. (1994): Nová Evropa. Brno: Doplněk.

MASARYK, T. G. (1995, 1996): Rusko a Evropa I-III. Praha: Ústav T. G. Masaryka

MASARYK, T. G. (2000): Otázka sociální I-II. Praha: Masarykův ústav AV ČR, Ústav T. G. Masaryka.

PROCHÁZKA, J. (1992): Jaká Evropa? Kurs světových dějin (1945-1989). Brno: Doplněk.

RÁDL, E. (1993): Válka Čechů s Němci. Praha: Melantrich.

ŠIMSA, M. (2018): Relativismus a (post)pravda v demokracii. Se třemi studiemi Ladislava Hejdánka. Ústí nad Labem: FF UJEP

PhDr. Martin Šimsa, Ph.D.

Katedra filosofie a humanitních studií

Pasteurova 13

40096 Ústí nad Labem

Archiv Jana Patočky

Centrum teoretických studií

Akademie věd ČR. Jilská 1 . Praha 1.

Martin.simsa@ujep.cz 